\title{
Evaluation and System of Effective Supply of Public Goods in Rural China from the Perspective of Rural Revitalization Optimization Path Research
}

\author{
Tang Yu \\ Liaoning Institute of Science and Technology, Benxi, Liaoning,117003, China \\ 493250079@qq.com
}

Keywords: Rural area public goods, Supply system, Efficient supply, Strategy

\begin{abstract}
This paper innovatively explores new perspectives and new ideas for the reform of rural public goods supply in China. Also clarify the new direction of China's rural public goods supply reform under the background of supply-side structural reform. It is of great theoretical value and practical significance to increase the effective supply of rural public goods and to supplement the short supply of public goods in rural China. The specific solutions and path selection will help to break through the unbalance problems of our economic development, promote the implementation of the strategy of rural development and revitalization and complete the realization of the goal of a well-off society in an all-round way.
\end{abstract}

\section{Introduction}

China gradually developed in the 40 years after the reform and opening up in the "three rural" business, has made historic achievements in the new era, there has been a breakthrough. However, there are still insufficient and uneven development of the outstanding problems in rural China. Agriculture, rural areas and farmers related to people's livelihood. As a result, there is an urgent need to implement the strategy of revitalizing the countryside, to solve the "three rural" problem fundamentally, in order to achieve strong agricultural development, rural construction and improve living standards of farmers. The 19th National Congress of the Communist Party of China made major decisions and plans for rural revitalization strategy, and the implementation of rural revitalization strategy into the party constitution. Central Economic Work Conference also focused strategy of revitalizing the countryside, as rural China will focus over the next few years. In 2018, the No.1 central document "CPC Central Committee and State Council on the implementation of rural revitalization strategy" proposes to promote the revitalization of the rural work force. Implementation of rural revitalization strategy is to solve a new era of Chinese society's principal contradiction, is the key to achieve "double one-hundred-year" goal, to achieve common prosperity of all the people of the core issues.

\section{Problems in the supply of public goods in rural China}

\subsection{Insufficient supply}

Since the founding of the People's Republic of China, the supply of public goods in rural China has made great progress. However, the shortage of supply and the lack of total volume are also indisputable facts. China's rural infrastructure and social basic services are difficult to meet farmers' longing for a better life. The gap between urban and rural areas is large, and it is still a prominent problem in building a well-off society in an all-round way and in the modernization of socialism in the new era.

\subsection{Unbalanced supply area}

China's agricultural infrastructure investment is characterized by uneven regional development. The investment environment in the eastern region is good, the scale of investment in infrastructure construction is large, the scope is wide, and the income is high, so that social capital can actively 
participate in the corresponding investment. The participation of social capital in agricultural infrastructure investment in the central and western regions is still in its infancy, and investment still needs to be strengthened. An important way to revitalize the countryside is to increase the supply of infrastructure in rural public goods and effectively shift the focus of infrastructure construction and social development to rural areas.

\subsection{Large difference between urban and rural supply}

The problems in the supply of rural public goods in China are not only reflected in the lack of supply and regional imbalances, but also in the significant urban-rural gap in the supply of public goods. Through the comparative analysis of the supply of public goods shared by urban and rural areas, this gap and the social unfairness that it sees can be clearly seen.

\subsection{Low supply efficiency}

The inefficient supply of rural public goods is characterized by low efficiency of use, capital budgeting and auditing in the form, lack of discussion on supply projects, supply that does not meet farmers' needs, and often wasteful and scarce supply. The rural public goods supply system is lagging behind and the management is not standardized. The low availability of rural public goods has affected the development and progress of the rural economy.

\subsection{Disconnection of supply demand}

The demand for public goods by farmers depends on the production and management activities, and the supply of rural public goods is not determined according to the needs of farmers' production and life. Instead, the decision-makers of higher-level governments and local governments arrange supply according to needs. Explain the mandatory and subjective nature of supply decisions, and do not grasp the needs of farmers.

\section{Analysis of the reasons for the effective supply deviation of rural public goods}

\subsection{Urban-rural dual structure exists for a long time}

A large part of China's current supply of rural public goods is due to the impact of China's development strategies, policies and systems since the founding of the country. China's urban-rural dual division has seriously affected China's rural development and caused insufficient supply of rural public goods.

\subsection{Unbalanced financial input}

The central public finances are insufficiently invested in the rural areas, the fiscal policy has a weak influence on the rural areas, the rural public finance system is not perfect, the grassroots government has limited financial resources, and the transfer payment system has not played a role. These reasons cause the urban and rural public goods supply to be uncoordinated achieve equalization.

\subsection{Insufficient motivation for farmers to participate in the supply of public goods}

The rural public goods supply system is single, the government investment is dominant, and there is no multi-supply mechanism for private and enterprise investment in public goods construction. Farmers are motivated and poorly involved in the construction of public affairs and facilities in rural areas. Due to the phenomenon of free-riding, many farmers are unwilling to bear the cost of supply. Some farmers are reluctant to invest in public goods from the interests.

\subsection{Inadequate funding mechanism}

First, the return on supply of funds is low, and social capital investment is poor. Second, insurance coverage is narrow and the variety is small. Third, the internal structure of supply investment is unreasonable. Fourth, a single fund-raising mechanism based on the government. Fifth, there is a lack of legal and legal protection. 


\section{Constructing the Optimized Path of Rural Public Goods Supply Reform System}

\subsection{Improve top-level planning and design}

The new era rural revitalization strategy covers a lot of content. It is gradually realized by the party, the government, and various departments under the coordinated efforts of long-term overall planning, and the implementation of various policies and the implementation of the system and regulations are the ultimate realization of the rural revitalization strategy to be an important guarantee.

Following the theoretical results of the socialist market economic system, we will give full play to the positive role of the "market mechanism" in resource allocation, and realize the advantages and weaknesses, complement each other, and complement each other. It is necessary to further deepen reforms, improve various systems and policy systems, fill short-boards, and guarantee the supply of rural public goods and the supply of social public services.

\subsection{Reform the functions of governments at all levels}

The 19th National Congress clearly proposed the rural revitalization and development plan, and the construction of beautiful villages requires policies to guarantee. Therefore, the government needs to introduce relevant new policies. Policies are the endogenous driving force for rural economic development. Increasing the supply of rural public goods can promote the development of rural economy. Reforming the supply of rural public goods is the key to achieving a well-off society in an all-round way.

Governments at all levels should implement supervisory functions in the supply of rural public goods, simplify administration, decentralize power, improve mechanisms, and standardize operations. Emphasis on collaborative sharing, encourage all parties involved in the supply to actively participate, give play to their respective strengths and capabilities, and ensure the rational and effective allocation of resources in rural areas.

\subsection{Strengthen government's regulatory construction}

The government should separate the functions of formulating policies from the functions of providing public services, abandon the monopoly position in the supply of rural public goods, and promote fair competition between the public and private sectors. On the basis of clarifying public and private property rights, improve the autonomy of management, allow various forms of joint reorganization, encourage relevant units to commit to performance standards, take responsibility for the results and efficiency of public goods supply, and establish direct and effective accountability mechanism.

The government should regulate the mode of operation of the main body and mobilize the enthusiasm of the main body. When the government and individuals simultaneously invest, they should clearly distinguish between public and private property rights and safeguard the due interests of the main body. Ensuring the benefits of agricultural technology inventions through legislation.

\subsection{Reforming the hierarchical responsibility system and fiscal transfer payment system of the central and local governments}

Clarify the mutual responsibility relationship between the lower and upper levels of government agencies, and pay adequate financial support for rural transfers in terms of fiscal budget. Improving the financial transfer payment system can effectively alleviate the financial difficulties of counties and towns, provide the necessary financial security for the supply of basic public goods in rural areas, and give full play to its positive role in narrowing the supply of urban and rural public goods.

It is necessary to earnestly expand the proportion of the central government's fiscal expenditure transfer payment in rural economic and social construction. It is necessary to optimize the transfer payment structure and increase the financial transfer payment, especially the proportion of general transfer payment that does not specify a specific use, so as to reduce the financial dependence of the rural government on the higher level government, so that the public goods supply of the rural government is closer to the target group. Reduce the proportion of the central government's various 
ministries and commissions in accordance with the "Articles" management transfer to the lower-level government special transfer payments, and clean up the current numerous projects, strengthen standardized management, optimize operational rules, and improve the use efficiency.

\section{Summary}

The central idea of implementing the rural revitalization strategy is to adhere to the priority development of agriculture and rural areas. Currently, agriculture, rural areas and farmers are not only short board for China to achieve a comprehensive well-off goal after 3 years, but also the future of China short board to achieve the goal of modernization. In 2017, No.1 Central Document clearly stated, "Agriculture and Rural padded short board, strengthening rural development basis." The key question padded agricultural and rural short board is to increase the rural public goods supply. Not only to "fill the short board" need to increase the supply of rural public goods, but also "reduce production capacity" also need to increase the supply of rural public goods, promote the rural economy growth without effective supply of rural public goods. At present, supply of public goods in rural China is less, poor quality, supply and demand contradiction, the existence of these problems show that China rural public goods supply in need of reform from the supply side. The main task of the reform of the supply of public goods in rural China is the increasing amount of rural public goods, improve the quality and efficiency of the supply, demand and comply fully reflect the wishes of farmers. The focus is to increase the effective supply of rural public goods, increasing rural infrastructure construction, promote the comprehensive development of various social undertakings in rural areas; rural innovation and decision-making of public goods supply, and improve the supervision mechanism and other aspects of the supply of rural public goods.

\section{Acknowledgment}

This paper is one of the research results of the Ph.D. Research Startup Fund Project of Liaoning Institute of Science and Technology (Grant No.1910B11).

\section{References}

[1] Tang Yu. Research on the Reform of Rural Public Goods Supply in China [D]. Liaoning University, 2018.

[2] Tian Meng. Giving Full Play to Democracy's Performance of People's Livelihood-Institutional Choice of Village-level Public Goods Supply [J]. Chinese Rural Economy, 2019.

[3] Chen Zhi. Research on Standardization of Rural Public Goods Supply in China [J]. Rural Economy, 2017. 